\title{
Yield and Economic Assessments of Five Cowpea Varieties in Cowpea- Maize Strip Intercropping in Limpopo Province, South Africa
}

\author{
Joseph Nwafor Akanwe Asiwe* and Katlego Alocia Maimela \\ University of Limpopo, Private Bag X1106, Sovenga 0727, South Africa \\ *For correspondence: Joseph.asiwe@ul.ac.za; josephasiwe012@ gmail.com \\ Received 13 June 2020; Accepted 24 July 2020; Published 10 December 2020
}

\begin{abstract}
Farmers' traditional cropping practice in Limpopo Province is to mix and broadcast crops at planting without definite row arrangement. Although this practice is very easy and cost-saving, it leads to low plant density, hinders farm input application, and results in low crop yields and poor return on investment. Strip intercropping, where crops are planted with definite row arrangement, reduces inter-species competition, optimises plant population, and increases crop yield. Five cowpea varieties i.e. 'TVu 13464', 'IT86D-1010', 'Glenda', 'IT82E-16' and 'IT87K-499-35' and maize was grown under strip intercropping, monocropping, and mixed intercropping as a control during two seasons. During both years, significant interactions were obtained between the cowpea varieties and the cropping systems in most of the variables measured. Cowpea sown in the strip intercropping performed better compared those sown in mixed intercropping. Cowpea varieties 'IT86D-1010', 'IT82E-16' and 'IT87K-499-35' harvested more grain yield under monocropping and strip intercropping than under mixed intercropping. The land equivalent ratio (LER) of strip intercropping during the two seasons ranged between 1.25 and 2.29 and was higher compared to mixed intercropping, which ranged between 0.50 and 1.32. In conclusion, cowpea varieties 'IT86D-1010', 'IT82E-16' and 'IT87K-499-35' sown with maize as strip intercropping resulted more profits under intercropping systems and were recommended for cultivation by farmers in the Limpopo region with low rainfall. Moreover, grain yield, LER, and net profit achieved by strip intercropping was three-fold more than mixed intercropping. (C) 2021 Friends Science Publishers
\end{abstract}

Keywords: Economic analysis; Grain yield; Land equivalent ratio; Vigna unguiculata; Zea mays

\section{Introduction}

Cowpea (Vigna unguiculata L.) is a protein-rich grain that complements staple cereal and starchy tuber crops. Cowpea is commonly used as a companion crop in many intercrop systems in sub-Saharan Africa (SSA), because of its ability to provide fixed atmospheric nitrogen to cereal crops in rotation (Asiwe 2009).

Many smallholder farmers in Limpopo Province practise intercropping of maize (Zea mays L.) with legumes to reduce the risk of crop failure, and enhance their production. Cereal-legume intercropping is commonly practised in South Africa, including the Limpopo Province, because of its yield advantage, greater stability, and lower risk to crop failure compared to monoculture (Kermah et al. 2017). Several research works have been reported recently on cereal-legume intercropping systems in South Africa and elsewhere. These include maize and pigeonpea (Kiwia et al. 2019); maize and dry bean (Phaseolus vulgaris L.) intercropping (Kutu and Asiwe 2010; Nthabiseng et al. 2015); and wheat (Triticum aestivum L.)-canola (Bracica juncea L.) intercropping (Khan et al. 2012; Tripathi et al. 2016). The traditional practice of farmers in Limpopo Province is the mixed intercropping, whereby crops are broadcasted at planting without definite row arrangement (Mucheru-Muna et al. 2010). Mixed intercropping hinders farm input application, results in non-optimal plant population (Mahapatra 2011), as well as intra and inter species competition (Muhammad et al. 2008; Chitra and Shrestha 2014), which lead to low crop yield and poor return on investment. This practice is not sustainable and economically viable.

Therefore, farmers in Limpopo Province are in dire need of an innovative intercropping system that is more sustainable and profit-oriented. Strip intercropping is a promising intercropping system where crops are planted with definite row arrangement, and has the potential of reducing inter-species competition, optimising plant population, and increasing crop yield and cash return (Singh and Ajeigbe 2007; Iderawumi and Friday 2013). The hypothesis of the study was to investigate whether the performance of the novel strip intercropping system would be better than or same as the traditional mixed intercropping currently being practised by farmers. Therefore, the objective of the study was to assess the performance and economic feasibility of five improved cowpea varieties under a cowpea-maize strip intercropping system compared to mixed intercropping system in Limpopo Province, South Africa. 


\section{Materials and Methods}

\section{Description of the study area}

The study was conducted at the University of Limpopo's

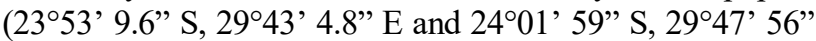
E, respectively) Experimental Farm (UL-Farm's) during 2015-2016 and 2016-2017. The site is characterised by erratic low rainfall, which ranges between 450 and $650 \mathrm{~mm}$ per annum, and falls predominantly during summer (Table 1).

\section{Experimental materials}

This consisted of five cowpea varieties (Glenda (check), IT87K-499-35, IT82E-16, IT86D-1010, and TVu-13464, a maize cultivar, and PAN 6479, obtained from PANNAR Seed Ltd., South Africa). The cowpea varieties were obtained from the gene bank of the University of Limpopo, South Africa.

\section{Treatments}

The experiment was laid out following randomized complete block design under split plot arrangement with three replications. The main plot factor was cropping system (intercrop and monocrop; the mono and mixed cropping systems were included as standard control practices) and the subplot factor was the varieties ('Glenda' (check), 'IT87K499-35', 'IT82E-16', 'IT86D-1010', and 'TVu-13464). The maize cultivar was planted at a spacing of $0.9 \mathrm{~m} \times 0.3 \mathrm{~m}$ with $4 \mathrm{~m}$ row length, giving a plant population of 52 and 40 plants per intercrop plot for maize and cowpea, respectively; and each plot area was $5.6 \mathrm{~m} \times 4.0 \mathrm{~m}$. The intercrop plots consisted of four rows of cowpea, sandwiched between two rows of maize. The monocrop plots consisted of six rows of cowpea and maize planted at an inter-row spacing of $0.75 \mathrm{~m}$ $\times 0.2 \mathrm{~m}$ and $0.9 \mathrm{~m} \times 0.3 \mathrm{~m}$, respectively. The net plot for each intercrop was $4.8 \times 4.0 \mathrm{~m}$, while that for monocrop (maize) was $4.8 \mathrm{~m} \times 4.0 \mathrm{~m}$, and $3.0 \mathrm{~m} \times 4.0 \mathrm{~m}$ for the cowpea monocrop.

\section{Crop management}

The land was conventionally tilled with tractor-mounted implements (disc plough and harrow) to enhance germination and seedling emergence. The trial was planted on 11 January 2016 during the 2015-2016 cropping season; whereas during the 2016-2017, it was planted on 13 December 2016. Roundup (isopropyl amine salt of glyphosate) and Dual (S-Metalachlor) were applied at the rates of $3 \mathrm{~L} \mathrm{ha}^{-1}$ and $0.5 \mathrm{~L} \mathrm{ha}^{-1}$, respectively, to control weeds before crop emergence. Manual weeding was subsequently conducted to control emerged weeds. Karate (LambdaCyhalothrin) and Aphox (Pirimicarb) were applied at the rate of $1 \mathrm{~L} \mathrm{ha}^{-1}$ and $500 \mathrm{~g} \mathrm{ha}^{-1}$ to control insect pests (blister beetles, aphids, and pod-sucking bugs) on cowpea from seedling stage until pod maturity. The trial was conducted under rain-fed conditions, and no fertilisers or irrigation were applied. Soil samples were collected from the experimental area, and the results of the analysis are shown in Table 2. The organic carbon, matter and available $\mathrm{P}$ were too different during the two years probably because the plots used during the two years were separate and different.

\section{Data collection}

The following parameters were measured in the same way during the two seasons to achieve the research study objectives. The number of days to $50 \%$ flowering was determined by counting the number of days from the date of plant emergence to the date that $50 \%$ of the plant population in each plot flowered. The number of days to $90 \%$ maturity was calculated by counting the number of days from plant emergence date to the date that $90 \%$ of the plant population in each plot matured. Plant height was determined by measuring the height of five plant samples with a meter rule.

\section{Plant harvesting}

Five plants from each plot were sampled randomly at maturity and total number of pods of these plants was counted and averaged to record number of pods/plants. The cowpea varieties were harvested in May of each year. For grain yield, sun-dried samples were harvested from four middle rows of each plot and threshed manually to obtain grain yield per plot. Weight of grains per plot was determined by weighing the grains on an electronic weighing balance, and the net yield was converted to $\mathrm{kg} \mathrm{ha}^{-1}$ using the following formula:

$$
\text { Grain yield }=(\text { grain weight }[\mathrm{kg}]) /\left(\text { area harvested }\left[\mathrm{m}^{2}\right]\right) \times 10000 \mathrm{~m}^{2}
$$

Maize grain was taken at maturity after harvesting the cobs. The yields were determined by weighing the grain from each net plot; and the weight was converted into $\mathrm{kg} / \mathrm{ha}$ using the following formula:

$$
\text { Grain yield }=(\text { grain weight }[\mathrm{kg}]) /\left(\text { area harvested }\left[\mathrm{m}^{2}\right]\right) \times 10000 \mathrm{~m}^{2}
$$

\section{Assessment of intercrop productivity}

For the assessment of the LER, the relative yields of cowpea and maize with their sole treatments were determined by using the following formulae (Mead and Willey 1980):

$$
\begin{aligned}
& \text { LER (Strip) }=\frac{\text { Intercropped yield of crop A }}{\text { Sole yield of crop A }}+\frac{\text { Intercrop yield of crop } B}{\text { Sole yield of crop B }} \\
& \text { LER (Strip) }=\frac{\text { Mixed intercropping yield }}{\text { Monocropping yield }}+\frac{\text { Mixed intercropping yield }}{\text { Monocropping yield }}
\end{aligned}
$$

\section{Data analysis}

Data collected during the two seasons were subjected to an analysis of variance technique using the Genstat 18 Version software to check the overall significance of data. Means that showed significant differences were separated using 
Duncan's new multiple range test (MRT) at $P \leq 0.05$ (Steel et al. 1997).

\section{Economic analysis}

A benefit-cost analysis was conducted to estimate the economic achievements of the different crop mixtures in the intercropping systems. The production costs of cowpea and maize included the cost of field preparation, seed, sowing, crop protection measures, harvesting, and processing. The total cost or revenue was estimated using the prevailing average market prices in Rand for the grain yield of cowpea and maize in South Africa. The amount in Rand was converted to USD \$ by dividing with the average exchange of 14.01 ZAR/\$. The total profit was calculated by subtracting the total cost from the total revenue, while the benefit-cost ratio (BCR) was calculated by dividing the total revenue by the total cost.

\section{Results}

The results showed that interactions between varieties and cropping system were significant $(P \leq 0.05)$ for most of the variables except plant height (during 2017) (Table 3). During the 2015/2016 season, varieties planted in the mixed intercropping plots flowered later than strip intercropping or monocropping. However, during 2016/2017, varieties planted in the mixed intercropping plots were the earliest to flower, followed by strip intercropping and monocropping. Similar trend was observed for the maturity of the varieties among the cropping systems. Maturity was later in the mixed intercropping than strip intercropping or monocropping. During 2017, mixed intercropping matured earlier than strip intercropping or monocropping. Results also show that plant height was observed to be shorter among plants in the mixed intercropping followed by strip intercropping. Varieties in the monocrop plots exhibited the tallest plants (Table 3). However, during 2017, no significant interaction was observed between varieties and cropping systems. The number of pods obtained from strip intercropping plots during 2015-2016 was highest followed by monocropping, and the lowest was obtained from mixed intercropping. However, during 2016-2017 season, mixed intercropping exhibited the highest number of pods followed by strip intercropping and monocropping. With respect to grain yield, the interaction results showed that during both seasons (Table 3 ) grain yield was consistently highest in the monocrop plots, followed by strip intercropping, while mixed intercropping achieved the lowest yield. Maize grain yield was significantly lower in mixed intercropping compared to strip intercropping or monocropping during both seasons (Table 3).

There were no significant $(P \leq 0.05)$ interactions observed between the varieties in the crop mixtures and cropping systems for LER during 2016-2017 while the effect was significant during 2015-2016 (Table 4). Higher
Table 1: Mean monthly rainfall, and minimum and maximum temperatures during both seasons

\begin{tabular}{lllllll}
\hline Months & $\begin{array}{r}\text { Minimum temperature } \\
\left({ }^{\circ} \mathrm{C}\right)\end{array}$ & \multicolumn{2}{c}{$\begin{array}{c}\text { Maximum temperature } \\
\left({ }^{\circ} \mathrm{C}\right)\end{array}$} & \multicolumn{2}{c}{$\begin{array}{c}\text { Total rainfall } \\
(\mathrm{mm})\end{array}$} \\
\cline { 2 - 7 } & 2016 & 2017 & 2016 & 2017 & 2016 & 2017 \\
\hline Dec & - & 16.9 & - & 27.2 & - & 120.9 \\
Jan & 17.0 & 12.1 & 28.6 & 25.3 & 87.4 & 101.7 \\
Feb & 17.6 & 12.2 & 29.1 & 24.6 & 57.9 & 40.3 \\
Mar & 15.7 & 06.0 & 28.1 & 24.0 & 126.7 & 23.1 \\
Apr & 11.6 & 9.67 & 26.2 & 23.5 & 5.3 & 30.4 \\
May & 13.5 & 3.4 & 25.8 & 21.4 & 1.0 & 11.4 \\
Jun & 7.4 & 5.43 & 19.1 & 19.7 & 3.2 & 1.04 \\
\hline \multicolumn{2}{l}{ Source: Agricultural } \\
Weather Station
\end{tabular}

Table 2: Pre-sowing physio-chemical analysis of soil in both seasons

\begin{tabular}{lll}
\hline Soil attributes & $2015-2016$ & $2016-2017$ \\
\hline Clay & 3 & 2 \\
Silt & 13 & 14 \\
Sand & 84 & 84 \\
Textural class & Sandy loam & Sandy loam \\
Chemical composition & & \\
pH & 7.4 & 8.2 \\
Organic carbon $(\%)$ & 1.84 & 0.58 \\
Organic matter $(\%)$ & 3.17 & 1.00 \\
Available P $(\mathrm{mg} / \mathrm{kg})$ & 2.05 & 1.19 \\
Ammonium N $(\mathrm{mg} / \mathrm{kg})$ & 0.95 & 0.79 \\
Nitrate N $(\mathrm{mg} / \mathrm{kg})$ & 0.19 & 0.16 \\
\hline
\end{tabular}

*P= Phosphorus; $\mathrm{N}=$ Nitrogen

LER were obtained from strip intercropping which was consistently higher than that obtained from mixed intercropping and monocropping (Table 4).

Economic analysis showed that revenue obtained was a function of the varieties' yield, and the variation was significant $(P \leq 0.05)$ among varieties and cropping systems (Table 5). The highest profits were obtained from crop mixtures of 'IT86D-1010' with maize followed by the 'IT82E-16' mixture and 'IT87K-499-35' with maize as strip intercropping while the lowest revenue was obtained from Glenda during both seasons. Likewise, strip intercropping of cowpea varieties 'IT86D-1010' and 'IT82E-16 with maize provided the highest profit and benefit-cost ratio followed by monocropping, and the lowest profit and benefit-cost ratio were achieved from mixed intercropping (Table 5).

\section{Discussion}

Results of the study indicated that strip intercropping performed significantly better than the mixed intercropping with respect to grain yield, LER and net returns (Table 3-5) and have great potential or attributes of improving the livelihood of farmers in Limpopo Province. The performance of any crop variety in any environment or cropping system is interplay of the variety's genetic characteristics which are expressed through the crop's physiological and morphological attributes to take advantage of the resources supplied by the environment or 
Asiwe and Maimela / Intl J Agric Biol, Vol 25, No 1, 2021

Table 3: Interactive effect of intercropping systems and cowpea varieties on days to $50 \%$ flowering, $90 \%$ maturity and yield component of cowpea, and maize yield

\begin{tabular}{|c|c|c|c|c|c|c|}
\hline \multirow[t]{2}{*}{ Varieties } & \multicolumn{3}{|c|}{$201-2016$} & \multicolumn{3}{|c|}{$2016-2017$} \\
\hline & Mono cropping & Strip intercropping & Mixed intercropping & Mono cropping & Strip intercropping & Mixed intercropping \\
\hline \multicolumn{7}{|c|}{ Number of days taken to complete $50 \%$ flowering (days) } \\
\hline Glenda & $53.00 \mathrm{c}$ & $53.00 \mathrm{c}$ & $53.00 \mathrm{c}$ & $60.67 \mathrm{a}$ & $60.00 \mathrm{a}$ & $51.67 \mathrm{ab}$ \\
\hline IT86D -1010 & $53.33 \mathrm{c}$ & $52.67 \mathrm{c}$ & $53.00 \mathrm{c}$ & $52.33 \mathrm{ab}$ & $52.00 \mathrm{ab}$ & $51.50 \mathrm{ab}$ \\
\hline IT87K-499-35 & $58.67 \mathrm{a}$ & $56.67 \mathrm{ab}$ & $53.00 \mathrm{c}$ & $50.67 \mathrm{ab}$ & $50.57 \mathrm{ab}$ & $51.67 \mathrm{ab}$ \\
\hline TVu 13464 & $47.67 d$ & $51.00 \mathrm{~cd}$ & $53.00 \mathrm{c}$ & $48.67 \mathrm{bc}$ & $48.67 \mathrm{bc}$ & $51.48 \mathrm{ab}$ \\
\hline \multicolumn{7}{|c|}{ Number of days taken to complete $90 \%$ maturity (days) } \\
\hline Glenda & $88.67 \mathrm{bc}$ & $91.67 \mathrm{ab}$ & $94.00 \mathrm{a}$ & $103.67 \mathrm{a}$ & $103.67 \mathrm{a}$ & $85.67 \mathrm{~d}$ \\
\hline IT82E-16 & $85.33 \mathrm{c}$ & $82.67 \mathrm{~cd}$ & $94.00 \mathrm{a}$ & $98.00 \mathrm{bc}$ & $98.00 \mathrm{bc}$ & $85.67 d$ \\
\hline IT86D -1010 & $86.00 \mathrm{c}$ & $85.00 \mathrm{c}$ & $94.00 \mathrm{a}$ & $88.00 \mathrm{~cd}$ & $88.00 \mathrm{~cd}$ & $84.50 d$ \\
\hline IT87K-499-35 & $95.00 \mathrm{a}$ & $91.00 \mathrm{ab}$ & $94.00 \mathrm{a}$ & $101.33 \mathrm{ab}$ & $101.00 \mathrm{ab}$ & $85.67 d$ \\
\hline TVu 13464 & $82.00 \mathrm{~cd}$ & $82.00 \mathrm{~cd}$ & $94.00 \mathrm{a}$ & $94.00 \mathrm{c}$ & $96.33 \mathrm{c}$ & $86.81 d$ \\
\hline \multicolumn{7}{|c|}{ Plant height $(\mathrm{cm})$} \\
\hline Glenda & $54.27 \mathrm{c}$ & $57.73 \mathrm{ab}$ & $40.53 \mathrm{de}$ & $59.60^{\mathrm{NS}}$ & 51.80 & 39.00 \\
\hline IT82E-16 & $54.4 \mathrm{c}$ & $51.2 \mathrm{~cd}$ & $40.53 \mathrm{de}$ & 35.87 & 34.47 & 39.00 \\
\hline IT87K-499-35 & $52.2 \mathrm{~cd}$ & $60.13 \mathrm{a}$ & $40.53 \mathrm{de}$ & 41.07 & 41.27 & 39.00 \\
\hline TVu 13464 & 39.8de & $39.93 \mathrm{de}$ & $40.53 \mathrm{de}$ & 29.60 & 29.53 & 39.95 \\
\hline \multicolumn{7}{|c|}{ Number of pods per plant } \\
\hline Glenda & $14.63 b c$ & $15.31 b c$ & $14.00 \mathrm{c}$ & $9.33 c$ & $9.73 \mathrm{c}$ & $16.13 \mathrm{a}$ \\
\hline IT82E-16 & $16.57 \mathrm{ab}$ & $18.77 \mathrm{a}$ & $14.00 \mathrm{c}$ & $10.87 \mathrm{bc}$ & $12.13 \mathrm{ab}$ & $16.13 \mathrm{a}$ \\
\hline IT86D -1010 & $16.47 \mathrm{ab}$ & $17.55 \mathrm{a}$ & $14.00 \mathrm{c}$ & $9.40 \mathrm{c}$ & $9.53 \mathrm{c}$ & $17.20 \mathrm{a}$ \\
\hline IT87K-499-35 & $14.80 \mathrm{bc}$ & $16.25 \mathrm{ab}$ & $14.00 \mathrm{c}$ & $10.47 b c$ & $12.07 \mathrm{ab}$ & $16.13 \mathrm{a}$ \\
\hline TVu 13464 & $16.07 \mathrm{ab}$ & 11.20 & $14.00 \mathrm{c}$ & $8.27 \mathrm{~cd}$ & $7.67 \mathrm{~cd}$ & $15.83 \mathrm{a}$ \\
\hline \multicolumn{7}{|c|}{ Grain yield $\left(\mathrm{kg} \mathrm{ha}^{-1}\right)$} \\
\hline Glenda & $1205 b c$ & $635 \mathrm{de}$ & $157 \mathrm{e}$ & $715 c$ & $573 d$ & $390 \mathrm{e}$ \\
\hline IT82E-16 & $1995 \mathrm{a}$ & $1140 \mathrm{c}$ & $157 \mathrm{e}$ & $1265 \mathrm{a}$ & $1025 \mathrm{ab}$ & $390 \mathrm{e}$ \\
\hline IT86D -1010 & $1525 \mathrm{ab}$ & $1052 \mathrm{c}$ & $157 \mathrm{e}$ & $1075 \mathrm{ab}$ & $1124 \mathrm{a}$ & $335 \mathrm{e}$ \\
\hline IT87K-499-35 & $920 \mathrm{~cd}$ & $815 d$ & $157 \mathrm{e}$ & $1280 \mathrm{a}$ & $887 b c$ & $390 \mathrm{e}$ \\
\hline TVu 13464 & $905 \mathrm{~cd}$ & $850 d$ & $157 \mathrm{e}$ & $760 \mathrm{c}$ & $680 \mathrm{~cd}$ & $409 \mathrm{e}$ \\
\hline \multicolumn{7}{|c|}{ Maize grain yield $\left(\mathrm{kg} \mathrm{ha}^{-1}\right)$} \\
\hline PAN 6479 & $3112 \mathrm{a}$ & $2996 a$ & $1320 \mathrm{~b}$ & $3237 \mathrm{a}$ & $3564 a$ & $2237 b$ \\
\hline
\end{tabular}

Table 4: Interactive effect of intercropping systems and cowpea varieties on land equivalent ratio

\begin{tabular}{llll}
\hline Crop mixtures & \multicolumn{2}{c}{ 2015-2016 } & Strip intercropping \\
\cline { 2 - 4 } & Strip intercropping & Mixed intercropping & Mixed intercropping \\
\hline Glenda + PAN 6479 & $1.25 \mathrm{c}$ & $0.56 \mathrm{~d}$ & $2.29^{\mathrm{NS}}$ \\
TVu 13464 + PAN 6479 & $1.48 \mathrm{~b}$ & $0.61 \mathrm{~d}$ & 1.81 \\
IT82E-16 + PAN 6479 & $1.58 \mathrm{a}$ & $0.50 \mathrm{~d}$ & 1.98 \\
IT86D -1010 + PAN 6479 & $1.65 \mathrm{a}$ & $0.54 \mathrm{~d}$ & 1.13 \\
IT87K-499-35 + PAN 6479 & $1.59 \mathrm{a}$ & $0.60 \mathrm{~d}$ & 1.07 \\
\hline
\end{tabular}

Means, with in columns and rows for each trait, with same letters are statistically similar with each other according to DNMR test at $P \leq 0.05$

NS= Non-significant

Table 5: Interactive effect of intercropping systems and cowpea varieties on net income and BCR

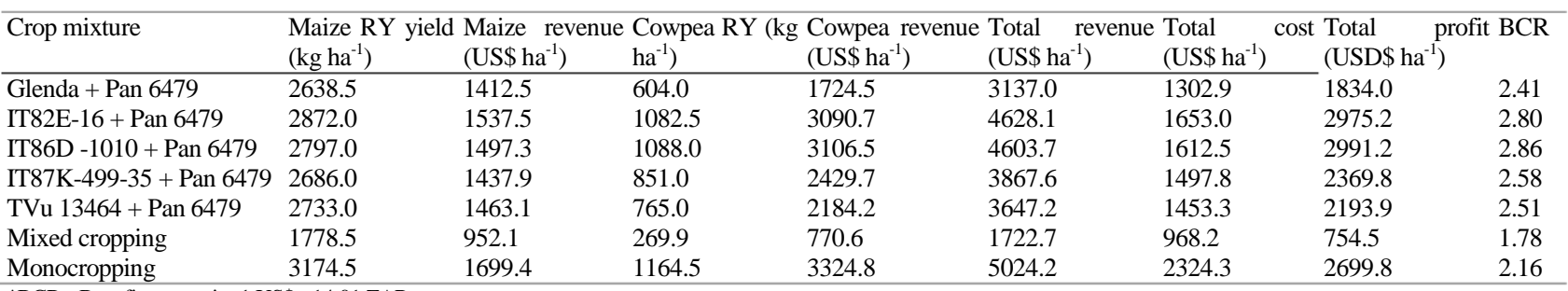

*BCR= Benefit-cost ratio; 1 US $\$=14.01$ ZAR

the cropping system. In this study, we obtained significant interactions between the varieties and the cropping systems for most variables measured (the number of days to $90 \%$ physiological maturity, plant height, number of pods per plant, grain yield and profit). This is an indication that the cropping systems influenced the performance of the cowpea varieties. The earliness to flower and physiological maturity are phenologically linked to enable the plant produce, and 
avoid losses associated with pests, drought or frost damage. In this study, we found that cowpea varieties flowered and matured differently among the cropping systems. This will offer the farmers the opportunity to make selection among the cowpea varieties, as well as giving them the empirical data to make an informed decision regarding the adoption of strip intercropping. For instance, farmers can select promising varieties that flower and mature early in the strip intercropping to prevent drought and frost damage. In this regard, 'TVu 13464' which attained earlier maturity in all the cropping systems during 2015-2016 and 2016-2017 than the local variety Glenda is an ideal variety for drought or pest evasion, as well as indicating that it is well adapted to mature early under the strip intercropping systems (Idahosa et al. 2010; Agoyi et al. 2017). Varieties that exhibit late maturity are known to be more vulnerable to drought and frost damage (Agbogidi and Egho 2012; Mafakheri et al. 2017).

The variations among the cowpea varieties in the yield components especially, the plant height, and the number of pods per plant as well as the grain yield point to the fact that the cropping systems influenced the performance of inherent genetic characteristics of the varieties, which were translated to their abilities to adapt to the environments (Fery 1985; Ichi et al. 2013). The cropping systems performed differently because the systems were able to discriminate the abilities of the varieties to compete for growth resources such as light, water, nutrients, space, and time. The results of this study corroborate the findings of past reports (Nwosu et al. 2013; Agyeman et al. 2014; Zerihun et al. 2016). Cropping systems (strip intercropping and monocropping) that supported higher plant height and pod numbers consistently produced higher grain yield, except during 2016-2017, when the number of pods was higher under mixed intercropping due to irregular plant density or no patterned plant arrangement, which led to less optimal plant population (Gabatshele et al. 2012). Iderawumi and Friday (2013) and Matusso et al. (2014) reported that mono-cropped cowpea plots produced significantly more pods per plant than those intercropped with maize. Consistently, higher grain yields obtained from cowpea varieties under monocropping during the two seasons is a clear indication that the varieties were bred and selected under a mono-cultural system. This may suggest that varieties to be utilised in an intercropping system must be developed and screened for selection under intercropping systems. This also justifies our decision to include several varieties so that farmers have the options to select the most promising and adapted varieties for cultivation.

In this study, strip intercropping produced three-fold more grain yield compared to the mixed intercropping. Nonetheless, maize grain yield was also higher in the case of strip intercropping compared with mixed intercropping due to efficient resource utilization and optimal plant population (Table 3). However, contrary to the observation of Matusso et al. (2014), Mango et al. (2018) reported that intercropping can generate higher crop yields and profits than monocropping.

The variations exhibited among the cowpea varieties during both seasons for most of the variables measured were due to their genetic characteristics and their interactions with weather variables (rainfall and temperature). A long period of rainfall during the reproductive phase is known to alter or extend the maturity of legumes, because it prolongs the flowering and podding period, which in turn leads to asynchronous maturity due to overlapping flowering. Therefore, more pods and grain yield were produced during the 2015-2016 cropping season, because rainfall and temperature distributions during the reproductive phase of the crop were better than they had been during the 20162017 season (Table 1). Zerihun et al. (2016) and Agoyi et al. (2017) also observed that adequate soil moisture during the reproductive stage is known to enhance grain filling, which can result in an increased grain yield.

Results of this study showed that the LER for strip intercropping system were greater than 1.00, which indicated that the system was more efficient in land and resource utilisation compared to mixed intercropping. According to Hamd et al. (2014), "when the LER $<1.00$, there is an obvious disadvantage caused by intercropping, and the available resources were used more efficiently by the sole crop than intercropping". Mariotti et al. (2006) and Kitonyo et al. (2013) also report that "when the LER is equal to 1 , there is neither an advantage nor a disadvantage of intercropping compared to a sole crop, but when the LER $>1.00$, it indicates that intercropping system has an advantage in terms of improved use of available resources for plant growth and development". In this study, the higher LER values (two-fold) with a range between 1.25 and 2.29 during both seasons were obtained for strip intercropping thus indicating that available land resources were utilized more efficiently compared to mixed intercropping with LER values ranging from 0.50 to 1.32 for both seasons. In addition, this is an indication that the higher the yield and more adapted the varieties, the more advantageous the benefit-cost ratio, and the profit farmers would earn in cultivating such varieties. According to Zhang et al. (2015), intercropping cereals with grain legumes has superior yield and economic benefits compared to sole cropping. The prospect of any cropping system for adoption depends on its comparative advantage in terms of yields and cash return over the sole crops (Seran and Brintha 2010; Imran et al. 2011; Asiwe and Madimabe 2020). The findings from this study corroborate these reports. Higher profit and benefitcost ratio were achieved from strip intercropping compared to the profit and benefit-cost ratio achieved from mixed intercropping.

\section{Conclusion}

Results revealed that grain yield, land equivalent ratio, net profits, and benefit:cost ratio obtained from strip intercropping were higher compared to mixed intercropping. 
Among the five varieties, 'IT82E-16', 'IT86D-1010', and 'IT87K-499-35' out-performed Glenda in terms of grain yield, land equivalent ration and net returns in strip intercropping system grown under rain-fed conditions. Therefore, these varieties are recommended for cultivation under strip intercropping system and rain-fed conditions of Limpopo Province, South Africa.

\section{Acknowledgements}

The first author acknowledges the financial grant received from the Water Research Commission, South Africa (Project number K5/2494) and the support from the University of Limpopo.

\section{Author Contributions}

Both authors contributed meticulously in the execution of the study during planting of the trial, data collection and collation, data analysis and the preparation of the First Manuscript Draft. The First author handled the corrections and correspondence from the reviewers.

\section{References}

Agbogidi OM, EO Egho (2012). Evaluation of eight varieties of cowpea (Vigna unguiculata (L.) Walp) in Asaba agro-ecological environment, Delta State, Nigeria. Eur J Sustain Dev 1:303-314

Agoyi EE, TL Odong, JB Tumuhairwe, G Chigeza, BW Diers, P Tukamuhabwa (2017). Genotype by environment effects on promiscuous nodulation in soybean (Glycine $\max$ L. Merrill). Agric Food Secur 6:29-42

Agyeman K, JN Berchie, I Osei-Bonsu, ET Nartey, JK Fordjour (2014). Growth and yield performance of improved cowpea (Vigna unguiculata L.) varieties in Ghana. Agric Sci 2:44-55

Asiwe JAN (2009). Needs assessment of cowpea production practices, constraints utilization in South Africa. Afr J Biotechnol 8:53835388

Asiwe JAN, KS Madimabe (2020). Performance and economic prospect of pigeonpea varieties in pigeonpea-maize strip intercropping in Limpopo Province. Intl J Agric Biol (In Press)

Chitra BK, J Shrestha (2014). Evaluating performance of maize hybrids in Terai Region of Nepal. World J Agric Res 2:22-25

Fery RL (1985). The genetics of cowpeas: A review of the world literature, pp:25-62. In: Cowpea Research, Production and Utilization. Singh SR, KO Rachie (Eds.). John Wiley and Sons, Chichester, England

Gabatshele M, T Legwaila, K Marokane, W Mojeremane (2012). Effects of intercropping on the performance of maize and cowpeas in Botswana. Intl J Agric For 2:307-310

Hamd WA, EM Shalaby, RA Dawood, AA Zohry (2014). Effect of cowpea (Vigna sinensis L.) with maize (Zea mays L.) intercropping on yield and its components. Intl Schol Sci Res Innov 8:1170-1176

Ichi JO, HE Igbadun, S Miko, AM Samndi (2013). Growth and yield response of selected cowpea (Vigna unguiculata (L.) Walp) varieties to irrigation interval and sowing date. Pac J Sci Technol 14:1-11

Idahosa DO, JE Alika, AU Omoregie (2010). Genetic variability, heritability and expected genetic advance as indices for yield and yield components selection in cowpea (Vigna unguiculata L. Walp). Acad Arena 2:22-26

Iderawumi AM, CE Friday (2013). Effects of geometric row arrangement growth and yield of cowpea in a maize-cowpea intercrop. Ind $J$ Innov Dev 2:816-820
Imran M, A Ali, M Waseem, M Tahir, AU Mohsin, M Shehzad, A Ghaffari, H Rehman (2011). Bio-economic assessment of sunflower mungbean intercropping system at different planting geometry. Intl Res J Agric Sci Soil Sci 1:126-136

Kermah M, AC Franke, S Adjei-Nsiah, BDK Ahiabor, RC Abaidoo, KE Giller (2017). Maize-grain legume intercropping for enhanced resource use efficiency and crop productivity in the Guinea savannah of northern Ghana. Field Crops Res 213:38-50

Khan M, M Khan, M Hussain, M Farooq, K Jabran, DJ Lee (2012). Bioeconomic assessment of different wheat-canola intercropping systems. Intl J Agric Biol 14:769-774

Kitonyo OM, GN Chemining'Wa, JW Muthomi (2013). Productivity of farmer-preferred maize varieties intercropped with beans in semiarid Kenya. Intl J Agron Agric Res 3:6-16

Kiwia A, D Kimani, R Harawa, B Jama, GW Sileshi (2019). Sustainable intensification with cereal-legume intercropping in Eastern and Southern Africa. Sustainability 2019; Article 2891

Kutu F, JAN Asiwe (2010). Assessment of maize and dry bean productivity under different intercrop systems and fertilization regimes. Afr $J$ Agric Res 5:1627-1631

Mafakheri K, MR Bihamta, AR Abbasi (2017). Assessment of genetic diversity in cowpea (Vigna unguiculate L.) germplasm using morphological and molecular characterisation. Cogent Food Agric 3; Article 1327092

Mahapatra SC (2011). Study of grass-legume intercropping system in terms of competition indices and monetary advantage index under acid lateritic soil of India. Amer J Exp Agric 1:683-693

Mango N, L Mapemba, H Tchale, C Makate, N Dunjana, M Lundy (2018). Maize value chain analysis: A case of smallholder maize production and marketing in selected areas of Malawi and Mozambique. Cogent Business Manage 5; Article 1503220

Mariotti AM, A Masoni, L Ercoli, I Arduini (2006). Forage potential of winter cereal-legume intercrops in organic farming. Ital J Agron 3:403-412

Matusso JMM, JN Mugwe, M Mucheru-Muna (2014). Potential role of growth and yield of cowpea in a maize-cowpea intercrop. Ind $J$ Innov Dev 2:816-820

Mead R, RW Willey (1980). The concept of a land equivalent ratio and advantages in yields for intercropping. Exp Agric 16:217-222

Mucheru-Muna M, P Pypers, D Mugendi, J Kung'u, J Mugwe, R Merckx, B Vanlauwe (2010). Staggered maize-legume intercrop arrangement robustly increases crop yields and economic returns in the highlands of central Kenya. Field Crops Res 115:132-139

Muhammad T, T Asif, A Asghar, A Muhammad, A Wasaya (2008). Comparative yield performance of different maize (Zea mays L.) hybrids under local conditions of Faisalabad-Pakistan. J Life Soc Sci 6:118-120

Nwosu DJ, BD Olatunbosun, IS Adetiloye (2013). Genetic variability, heritability, and genetic advance in cowpea genotypes in two agroecological environments. Green J Biol Sci 3:202-207

Nthabiseng TR, IK Mariga, PM Mabapa (2015). Response of a maize or dry bean intercrop to maize density and dry bean arrangement under rainfed conditions. Intl J Agron Agric Res 6:18-29

Seran TH, I Brintha (2010). Review on maize based intercropping. J Agron 9:135-145

Singh BB, HA Ajeigbe (2007). Improved cowpea- cereal. Based cropping systems for household food security and poverty reduction in West Africa. J Crop Improv 19:157-172

Steel RGD, JH Torrie, DA Dicky (1997). Principles and Procedures of Statistics: A Biometrical Approach, $3^{\text {rd }}$ edn. McGraw Hill, Inc., Book Co., New York, USA

Tripathi S, S Chander, R Meena (2016). Intercropping of canola and mustard with wheat for higher profitability. $J$ Wheat Res 8:30-33

Zerihun A, T Shiferaw, T Meseret (2016). Multiple advantages of cowpea (Vigna unguiculata L.) in maize based cropping systems: Used as live stake for climbing bean with phosphorus rates and maize productivity enhancement in monocropping. J Nat Sci Res 6:8-18

Zhang Y, J Liu, J Zhang, H Liu, S Liu, L Zhai, H Wang, Q Lei, T Ren, C Yin (2015). Row ratios of intercropping maize and soybean can affect agronomic efficiency of the system and subsequent wheat. PLoS One 6; Article e0129245 